\title{
Weathering Performance of Mulberry Wood with UV Varnish Applied and Its Mechanical Properties
}

\author{
Vedat Çavuş* \\ Mulberry wood is used in carpentry, fences, turnery, and garden \\ architecture. In this study, various mechanical properties (modulus of \\ rupture, modulus of elasticity, Janka hardness, and screw holding \\ resistance) of mulberry (Morus alba) wood and its weathering performance \\ after applying 3- and 5-layer UV system parquet varnishes with different \\ surface applications were investigated. The varnished materials were \\ aged using UV lamps for $252 \mathrm{~h}$ and $504 \mathrm{~h}$, and the aged specimens were \\ compared with non-aged specimens. The results of the variance analyses \\ found that all tests were significant. According to the results, it was found \\ that while the yellow color $\left(b^{\star}\right)$ tone value, lightness, and glossiness \\ (perpendicular $(\perp)$ and parallel $(\|)$ direction at $20^{\circ}, 60^{\circ}$, and $85^{\circ}$ angles) \\ values decreased for both varnish applications, the pendulum hardness \\ value increased. The adhesion strength (pull-off) test (MPa) to the surface \\ first decreased and then increased.
}

Keywords: UV system varnish; Glossiness; Color; Surface adhesion resistance; Pendulum hardness

Contact information: Izmir Katip Celebi University, Faculty of Forestry, Forest Industry Engineering Department, Cigli/Izmir 35620 Turkey; *Corresponding author: vedatcavus@hotmail.com

\section{INTRODUCTION}

Ultraviolet (UV) cured coatings are mostly utilized in industrial applications where thermal curing is almost impossible to use (Schwalm 2006). UV-cured varnishes have various benefits, e.g., wide-ranging and easy applications, decreased volatile organic compound emission, excellent mechanical properties, and good optical properties (Schwalm 2006; Blanchard et al. 2009).

Generally, UV-cured coatings are primarily applied to heat-sensitive surfaces, e.g., wooden furniture, parquet, or plastic products (Schwalm 2006). In previous studies, various wood species, e.g., iroko, chestnut, limba, sapelli (Ayata and Çavuş 2018), oak (Gurleyen et al. 2019), Persian silk (Gurleyen 2020), lemon (Ayata 2019), apricot (Ayata et al. 2021), beech (Ayata et al. 2017), scotch pine (Gurleyen et al. 2017), and doussie (Gurleyen 2021) were studied using UV system varnishes. The UV system varnishes were applied, and various tests, e.g., scratch, color, surface adhesion resistance, gloss, pendulum hardness, etc., were performed on the varnished materials, in addition to aging applications, e.g., thermal, natural, artificial, etc.

As stated in past literature, mulberry (Morus alba) wood is an important material in fencing, carpentry, turning, and garden architecture; it is valuable since it is durable, hard, and accepts polish (Tekeli 1973). In addition, it is used for making sports equipment, chests, furniture, car wheels, and musical instruments, e.g., reeds, etc. (Yaltırık and Efe 1994). In this study, the color, glossiness, pendulum hardness, and adhesion resistance properties of the mulberry wood surfaces varnished with 3 and 5 layers of UV varnish were determined after $252 \mathrm{~h}$ and $504 \mathrm{~h}$ of aging. In addition, the Janka hardness (tangent, radial, 
and transverse) values of the mulberry wood, the modulus of rupture, the modulus of elasticity, the screw holding (tangent, radial, and transverse) resistance and the air dry density values were also investigated. According to previous literature, it was found that no research has been done on the application of UV varnish to the top surface to this wood.

\section{EXPERIMENTAL}

\section{Wood Material}

Mulberry (Morus alba) wood samples were obtained from a private lumber company from located in Izmir City, Turkey. The unvarnished color properties of the mulberry wood used in the study were determined as $L^{*}: 60.85, a^{*}: 8.83$, and $b^{*}: 29.17$. Wood specimens with the following dimensions were prepared: $50 \mathrm{~cm} \times 10 \mathrm{~cm} \times 2 \mathrm{~cm}$ (longitudinal $\mathrm{x}$ tangential $\mathrm{x}$ radial). Afterwards, air conditioning processes, according to TSE TS standard 2471 (1976), at a temperature of $20^{\circ} \mathrm{C} \pm 2{ }^{\circ} \mathrm{C}$ and a relative humidity of $65 \% \pm 3 \%$, were applied to the samples.

\section{Application of the UV System Parquet Varnish}

The mulberry wood was cut into samples of $50 \mathrm{~cm} \times 10 \mathrm{~cm} \times 1.7 \mathrm{~cm}$. The UV varnishes (3 layers and 5 layers) were applied to the mulberry samples, according to industrial application methods at the KPS Company (Duzce City, Turkey). The production stages are shown in Table 1. Information about these chemicals is disclosed in the article describing the research conducted by Ayata (2019). The coated samples were conditioned in a special room (at a $12 \%$ equilibrium moisture content, a temperature of $20{ }^{\circ} \mathrm{C} \pm 2{ }^{\circ} \mathrm{C}$, and a relative humidity of $65 \pm 5 \%$ ) according to TSE TS standard 2471 (1976). It has been discussed in the literature that the varnish types used give different results with other wood species (Ayata 2019; Ayata et al. 2021; Gürleyen 2020, 2021).

Table 1. UV System Parquet Production Stages

\begin{tabular}{|c|c|}
\hline 3 Layers & 5 Layers \\
\hline Using 80 and 120 numbered sanders on a calibrated sander \\
\hline Clear UV curing hydro primer for $10 \mathrm{~g} / \mathrm{m}^{2}$ and drying at $70{ }^{\circ} \mathrm{C}$ \\
\hline $\begin{array}{c}\text { UV curtain coating high gloss for } 8 \mathrm{~g} / \mathrm{m}^{2} \\
\text { 2 times --> UV lamp drying }\end{array}$ & UV clear curing sealer for $20 \mathrm{~g} / \mathrm{m}^{2}$ and drying at $70^{\circ} \mathrm{C}$ \\
\hline Total $\left(177 \mathrm{~mJ} / \mathrm{cm}^{2}\right)$ & UV clear curing sealer for $10 \mathrm{~g} / \mathrm{m}^{2}$ and drying at $70^{\circ} \mathrm{C}$ \\
\hline Using 280 and 320 numbered sanders on a calibrated sander \\
\hline \multicolumn{2}{|c|}{ Clear mat UV oil for $8 \mathrm{~g} / \mathrm{m}^{2}$} \\
\hline \multicolumn{2}{|c|}{ UV lamp drying $\left(71 \mathrm{~mJ} / \mathrm{cm}^{2}\right)$} \\
\hline \multicolumn{2}{|c|}{ Clear mat UV oil for $8 \mathrm{~g} / \mathrm{m}^{2}$} \\
\hline 2 times ---> UV lamp drying Total $\left(314 \mathrm{~mJ} / \mathrm{cm}^{2}\right)$ \\
\hline
\end{tabular}

\section{Methods}

Artificial weathering

Samples varnished with the 3- and 5-layer UV system were exposed to a QUV weathering tester (Q-Lab, Westlake, OH), using ISO standard 4892-3 (2016) (a 15 min water spray, at a light intensity of 0.67 , a temperature of $50{ }^{\circ} \mathrm{C}$, and $8 \mathrm{~h}$ of ultraviolet light from UVA-340 lamps) for either $252 \mathrm{~h}$ or $504 \mathrm{~h}$. 


\section{Determination of the pendulum hardness and surface adhesion strength}

The pendulum hardness (PH) was determined using a Konig device (Pendulum Damping Tester, Model 299/300 Erichsen, Hemer, Germany), according to ASTM standard D 4366 (1995). The surface adhesion strength was measured according to ASTM D standard 4541 (1995) using a PosiTest AT-A pull-off adhesion tester (automatic) (DeFelsko Corporation, Ogdensburg, NY) for the aged and unaged mulberry wood samples varnished with the 3- and 5-layer UV system $(10 \mathrm{~cm} \times 10 \mathrm{~cm} \times 1.7 \mathrm{~cm})$. A room with an adhesion resistance temperature of $20{ }^{\circ} \mathrm{C}$ was also set. Cylinders (a $20 \mathrm{~mm}$ diameter) and 404 fast plastic steel glue (2.4.6-tris -dimethylaminomethyl phenol) (404 Kimya ve Sanayi Ticaret A.S., Istanbul, Turkey) used. The coated samples were air-dried for $24 \mathrm{~h}$, after which the glue residue was removed with a cutter. The adhesion X (MPa) was determined using Eq. 1,

$$
X=4 F / \pi \cdot d^{2}
$$

where $d$ is the diameter of the experiment cylinder (mm), and $F$ is the rupture force $(\mathrm{N})$ (Ayata 2019).

\section{Determination of the glossiness and color measurement}

An ETB-0833 gloss meter (Vetus Elec. Tech. Co., Ltd., Hefei, China) was used for glossiness measurements according to ISO standard 2813 (1994). The measurements were taken in the parallel and perpendicular direction at $20^{\circ}, 60^{\circ}$, and $85^{\circ}$ angles. A CS- $10(\mathrm{CHN}$ Spec., Hangzhou City, China) colorimeter with a $8^{\circ}$ diffused illumination, a CIE D65 light source, and a CIE $10^{\circ}$ standard observer was used to determine the $b^{*}$ (yellow color tone), $a^{*}$ (red color tone), and $L^{*}$ (lightness), according to ASTM standard D 2244-07 (2007). The CIELAB system is defined as follows: The $L^{*}$ axis represents lightness (from 100 white to 0 black), $b^{*}$ is the yellow (+) to blue (-) tone, and $a^{*}$ is the red (+) to green (-) tone (Ayata 2019). The total color difference was determined using Eq. 2 through Eq. 5,

$$
\begin{aligned}
& \Delta E^{*}=\left[\left(\Delta a^{*}\right)^{2}+\left(\Delta L^{*}\right)^{2}+\left(\Delta b^{*}\right)^{2}\right]^{1 / 2} \\
& \Delta b^{*}=b^{*} \text { weathered UV varnish coated }-b^{*} \text { unweathered UV varnish coated } \\
& \Delta L^{*}=L^{*} \text { weathered UV varnish coated }-L^{*} \text { unweathered UV varnish coated } \\
& \Delta a^{*}=a^{*} \text { weathered UV varnish coated }-a^{*} \text { unweathered UV varnish coated }
\end{aligned}
$$

\section{Determination of the mechanical properties}

The tests to determine the mechanical properties were performed according to TSE TS standard 2474 (1976) for the modulus of rupture (MOR) (N/mm²) (a sample size of 2 $\mathrm{cm} \times 2 \mathrm{~cm} \times 36 \mathrm{~cm}$ with 10 total samples), TSE TS standard 2478 (1976) for the modulus of elasticity (MOE) $\left(\mathrm{N} / \mathrm{mm}^{2}\right)$, TSE TS standard 2477 (1976) for the impact bending strength (IBS) $\left(\mathrm{kgm} / \mathrm{cm}^{2}\right.$ ) (a sample size of $2 \mathrm{~cm}$ x $2 \mathrm{~cm} \times 30 \mathrm{~cm}$ with 10 total samples), TSE TS standard 2479 (1976) for the static hardness (JH) $\left(\mathrm{N} / \mathrm{mm}^{2}\right)$ (a sample size of $5 \mathrm{~cm}$ x $5 \mathrm{~cm}$ x $5 \mathrm{~cm}$ with 15 total samples), and TSE TS EN standard 13446 (2005) for the screw holding resistance $(\mathrm{SHR})\left(\mathrm{N} / \mathrm{mm}^{2}\right.$ ) (a sample size of $5 \mathrm{~cm}$ x $5 \mathrm{~cm}$ x $5 \mathrm{~cm}$ with 15 total samples). For the screw holding resistance, the front hole diameter was $2.5 \mathrm{~mm}$, the screw diameter was $4 \mathrm{~mm}$, the screw length was $50 \mathrm{~mm}$, and the screw penetration depth was 20 $\mathrm{mm}$. The distance between the supports was set at 30 in for the bending resistance and 24 $\mathrm{cm}$ for the shock resistance. During the bending resistance and shock resistance test, the force was applied to the radial surface. 


\section{Statistical analysis}

In the study, the average values, maximum and minimum values, and standard deviations of the variance analysis were calculated with the SPSS 17 program using the data tests. The obtained results are presented in Tables 2 and 3. In addition, a total of 1305 measurements (color 360 plus gloss 720 plus adhesion 30 plus pendulum hardness 60 plus mechanical tests 135 equals 1305) were taken in the study.

\section{RESULTS AND DISCUSSION}

In Table 2, JH, MOR, MOE, IBS, SHR, and air dry density values of mulberry tree, as obtained in the present work, are given in the first column of data. The air dry density was $659.19 \mathrm{~kg} / \mathrm{m}^{3}$, the MOR was $116.06 \mathrm{~N} / \mathrm{mm}^{2}$, the MOE was $9603.60 \mathrm{~N} / \mathrm{mm}^{2}$, the IBS was $0.313 \mathrm{kgm} / \mathrm{cm}^{2}$, the $\mathrm{JH}$ was $67.81 \mathrm{~N} / \mathrm{mm}^{2}, 64.38 \mathrm{~N} / \mathrm{mm}^{2}$, and $81.29 \mathrm{~N} / \mathrm{mm}^{2}$ in the tangent, radial, and transverse direction, respectively, and the SHR was $39.99 \mathrm{~N} / \mathrm{mm}^{2}$, $40.00 \mathrm{~N} / \mathrm{mm}^{2}$, and $39.16 \mathrm{~N} / \mathrm{mm}^{2}$ in the tangent, radial and transverse direction, respectively.

Table 2. Mechanical Properties of Mulberry Wood and Various Other Species

\begin{tabular}{|c|c|c|c|c|c|}
\hline \multicolumn{2}{|c|}{ Test Name } & Mulberry & Bitter Orange & Maple & Fragrant Juniper \\
\hline \multicolumn{2}{|c|}{ Air dry density $\left(\mathrm{kg} / \mathrm{m}^{3}\right)$} & 659.19 & 868.00 & 574.00 & - \\
\hline \multicolumn{2}{|c|}{$\operatorname{MOR}\left(\mathrm{N} / \mathrm{mm}^{2}\right)$} & 116.06 & 134.70 & 78.00 & 93.80 \\
\hline \multicolumn{2}{|c|}{$\operatorname{MOE}\left(\mathrm{N} / \mathrm{mm}^{2}\right)$} & 9603.60 & 8988.00 & 6808.00 & 6701.50 \\
\hline \multicolumn{2}{|c|}{ IBS $\left(\mathrm{kgm} / \mathrm{cm}^{2}\right)$} & 0.313 & 0.683 & 0.217 & 0.280 \\
\hline \multirow{3}{*}{$\underset{\left(\mathrm{N} / \mathrm{mm}^{2}\right)}{\mathrm{JH}}$} & Tangent & 67.81 & - & - & 45.70 \\
\hline & Radial & 64.38 & - & - & 43.80 \\
\hline & Transverse & 81.29 & - & - & 62.00 \\
\hline \multirow{4}{*}{$\begin{array}{c}\text { SHR } \\
\left(\mathrm{N} / \mathrm{mm}^{2}\right)\end{array}$} & Tangent & 39.99 & 55.80 & 35.10 & - \\
\hline & Radial & 40.00 & 57.70 & 33.10 & - \\
\hline & Transverse & 39.16 & 52.60 & 40.90 & - \\
\hline & & In this study & Çavuş (2020a) & Efe (2020) & Çavuş (2020b) \\
\hline
\end{tabular}

The results for the total color $\left(\Delta a^{*}, \Delta L^{*}, \Delta b^{*}\right.$, and $\left.\Delta E^{*}\right)$ differences and the SPSS results of the color parameters $\left(L^{*}, b^{*}\right.$, and $\left.a^{*}\right)$, glossiness values parallel to the fibers at $20^{\circ}, 60^{\circ}$, and $85^{\circ}$ angles, the $\mathrm{PH}$, and the surface adhesion resistance of the samples varnished with 3- and 5-layer UV applications before and after undergoing weathering are presented in Table 3. After the weathering effect was applied, the samples varnished with 3- and 5-layer UV applications, no cracks, blisters, etc. were observed. When Table 3 was examined, it was found that the $b^{*}$ and $L^{*} 3$ - and 5-layers values decreased as the aging time increased, while the $a^{*} 3$ - and 5-layers values increased at the end of the $252 \mathrm{~h}$ aging process but decreased by the end of $504 \mathrm{~h}$ aging process. As stated in previous studies, a decrease in the $L^{*}$ value means a darkening of the color tone and an increase in the $L^{*}$ value may mean that the color is lighter (Söğütlü and Sönmez 2006). In this study, the decrease in the $L^{*}$ values of the samples varnished with UV 3- and 5-layers applications showed that darkening occurred after aging. When focused on the glossiness values, the glossiness measurement values parallel to the fibers at $20^{\circ}$ and $60^{\circ}$ angles were greater than the measurement values perpendicular to the fibers. In addition, the glossiness values of the samples varnished with a UV 5-layer application were found to be higher than the glossiness values from the UV 3-layer application. 
Table 3. Statistical Data for All Tests

\begin{tabular}{|c|c|c|c|c|c|c|c|c|c|c|}
\hline \multirow{2}{*}{$\begin{array}{c}\text { Varnish } \\
\text { Type }\end{array}$} & \multirow{2}{*}{$\begin{array}{c}\text { Weathering } \\
\text { Period }\end{array}$} & \multirow[b]{2}{*}{$\mathbf{N}$} & \multicolumn{4}{|c|}{ Lightness $\left(L^{*}\right)$} & \multirow[b]{2}{*}{$\mathbf{N}$} & \multicolumn{3}{|c|}{ Red Color $\left(a^{\star}\right)$ Tone } \\
\hline & & & Mean & $H G$ & \multicolumn{2}{|c|}{ SS } & & Mean & $H G$ & SS \\
\hline \multirow{3}{*}{$\begin{array}{c}3 \\
\text { layers }\end{array}$} & Control & 20 & 65.26 & $A^{*}$ & \multicolumn{2}{|c|}{0.75} & 20 & 10.14 & $\mathrm{E}^{\star *}$ & 0.18 \\
\hline & $252 \mathrm{~h}$ & 20 & 37.49 & $\mathrm{D}$ & \multicolumn{2}{|c|}{0.83} & 20 & 19.50 & $A^{*}$ & 0.53 \\
\hline & $504 \mathrm{~h}$ & 20 & 32.16 & $\mathrm{E}^{\star *}$ & \multicolumn{2}{|c|}{0.52} & 20 & 16.04 & $\mathrm{C}$ & 0.43 \\
\hline \multirow{3}{*}{$\begin{array}{c}5 \\
\text { layers }\end{array}$} & Control & 20 & 58.55 & $\mathrm{~B}$ & \multicolumn{2}{|c|}{1.07} & 20 & 11.48 & $\mathrm{D}$ & 0.50 \\
\hline & $252 \mathrm{~h}$ & 20 & 42.71 & C & \multicolumn{2}{|c|}{0.43} & 20 & 16.34 & B & 0.27 \\
\hline & $504 \mathrm{~h}$ & 20 & 37.59 & $\mathrm{D}$ & \multicolumn{2}{|c|}{0.64} & 20 & 16.31 & $\mathrm{~B}$ & 0.40 \\
\hline \multirow{2}{*}{$\begin{array}{c}\text { Varnish } \\
\text { Type }\end{array}$} & Weathering & \multirow{2}{*}{$\mathbf{N}$} & \multicolumn{4}{|c|}{ Yellow Color $\left(b^{\star}\right)$ Tone } & \multirow{2}{*}{$\mathbf{N}$} & \multicolumn{3}{|c|}{ Pendulum Hardness } \\
\hline & Period & & Mean & $H G$ & $S$ & & & Mean & $H G$ & SS \\
\hline & Control & 20 & 43.39 & $A^{*}$ & 0 . & & 10 & 70.60 & $E^{\star *}$ & 7.50 \\
\hline Javerc & $252 \mathrm{~h}$ & 20 & 25.26 & $\mathrm{C}$ & 1. & & 10 & 78.60 & $\mathrm{D}$ & 9.12 \\
\hline & $504 \mathrm{~h}$ & 20 & 12.74 & $E^{\star *}$ & 0. & & 10 & 78.00 & D & 3.97 \\
\hline & Control & 20 & 39.92 & $\mathrm{~B}$ & 0. & & 10 & 95.70 & $\mathrm{C}$ & 6.04 \\
\hline $\begin{array}{c}5 \\
\text { laverc }\end{array}$ & $252 \mathrm{~h}$ & 20 & 24.50 & $\mathrm{D}$ & 0. & & 10 & 113.50 & $\mathrm{~B}$ & 5.48 \\
\hline & $504 \mathrm{~h}$ & 20 & 15.14 & $E$ & 0. & & 10 & 125.80 & $A^{*}$ & 10.72 \\
\hline Varnish & Weathering & & Tot & Color & ifferenc & & $\mathbf{N}$ & Adh & sion & (Pa) \\
\hline Type & Period & $\mathbf{N}$ & $\Delta L^{*}$ & $\Delta a^{*}$ & $\Delta b^{*}$ & $\Delta E^{*}$ & $\mathbf{N}$ & Mean & $H G$ & SS \\
\hline & Control & 20 & - & - & - & - & 5 & 2.004 & C & 0.22 \\
\hline lavers & $252 \mathrm{~h}$ & 20 & -27.77 & 9.36 & -18.13 & 34.46 & 5 & 1.750 & $\mathrm{D}$ & 0.14 \\
\hline & $504 \mathrm{~h}$ & 20 & -33.10 & 5.90 & -30.65 & 45.50 & 5 & 2.734 & $A^{*}$ & 0.31 \\
\hline & Control & 20 & - & - & - & - & 5 & 2.260 & B & 0.19 \\
\hline $\begin{array}{c}5 \\
\text { lavers }\end{array}$ & $252 \mathrm{~h}$ & 20 & -15.84 & 4.86 & -15.42 & 22.63 & 5 & 0.956 & $E^{\star *}$ & 0.09 \\
\hline & $504 \mathrm{~h}$ & 20 & -20.96 & 4.83 & -24.78 & 32.81 & 5 & 1.672 & $\mathrm{D}$ & 0.13 \\
\hline Varnish & Weathering & $\mathbf{N}$ & & ossin & ss $\mid 2^{\circ}$ & & & Glos & iness & $20^{\circ}$ \\
\hline Type & Period & iv & Mean & $H G$ & $S$ & & $\mathbf{N}$ & Mean & $H G$ & SS \\
\hline & Control & 20 & 0.68 & C & 0. & & 20 & 0.60 & C & 0.00 \\
\hline lavers & $252 \mathrm{~h}$ & 20 & 0.13 & $E$ & 0. & & 20 & 0.10 & $E$ & 0.00 \\
\hline & $504 \mathrm{~h}$ & 20 & 0.10 & $E^{* *}$ & 0. & & 20 & 0.06 & $\mathrm{~F}^{\star}$ & 0.05 \\
\hline & Control & 20 & 2.42 & $A^{*}$ & 0. & & 20 & 2.40 & $A^{*}$ & 0.00 \\
\hline $\begin{array}{c}5 \\
\text { lavers }\end{array}$ & $252 \mathrm{~h}$ & 20 & 1.24 & $B$ & 0. & & 20 & 1.10 & $\mathrm{~B}$ & 0.02 \\
\hline & $504 \mathrm{~h}$ & 20 & 0.35 & $\mathrm{D}$ & 0 . & & 20 & 0.30 & $\mathrm{D}$ & 0.00 \\
\hline Varnish & Weathering & $\mathbf{N}$ & & ssint & $60^{\circ}$ & & $\mathbf{N}$ & Glos & iness & $60^{\circ}$ \\
\hline Гype & Period & $\mathbf{N}$ & Mean & $H G$ & $S$ & & $\mathbf{N}$ & Mean & $H G$ & $S S$ \\
\hline & Control & 20 & 5.06 & $\mathrm{C}$ & 0 . & & 20 & 4.33 & $\mathrm{C}$ & 0.13 \\
\hline $\begin{array}{c}3 \\
\text { lavers }\end{array}$ & $252 \mathrm{~h}$ & 20 & 1.66 & $E$ & 0. & & 20 & 1.67 & $E$ & 0.07 \\
\hline & $504 \mathrm{~h}$ & 20 & 1.15 & $\mathrm{~F}^{\star *}$ & 0. & & 20 & 0.88 & $\mathrm{~F}^{* *}$ & 0.04 \\
\hline & Control & 20 & 18.93 & $A^{*}$ & 0 . & & 20 & 16.37 & $A^{*}$ & 0.11 \\
\hline lavers & $252 \mathrm{~h}$ & 20 & 11.27 & $\mathrm{~B}$ & 0. & & 20 & 10.31 & $\mathrm{~B}$ & 0.15 \\
\hline & $504 \mathrm{~h}$ & 20 & 3.45 & $\mathrm{D}$ & 0 . & & 20 & 3.33 & $\mathrm{D}$ & 0.05 \\
\hline Varnish & Weathering & $\mathbf{N}$ & & ossin & \begin{tabular}{l||l|l}
5 & $85^{\circ}$ \\
\end{tabular} & & $\mathbf{N}$ & Glos & iness & $85^{\circ}$ \\
\hline Type & Period & iv & Mean & $H G$ & $S$ & & iv & Mean & $H G$ & SS \\
\hline & Control & 20 & 8.32 & $\mathrm{D}$ & 0. & & 20 & 3.04 & $\mathrm{D}$ & 0.42 \\
\hline lavers & $252 \mathrm{~h}$ & 20 & 3.64 & $E$ & 0. & & 20 & 1.34 & $\mathrm{E}$ & 0.11 \\
\hline & $504 \mathrm{~h}$ & 20 & 1.40 & $\mathrm{~F}^{\star *}$ & 0 . & & 20 & 0.36 & $\mathrm{~F}^{\star \star}$ & 0.22 \\
\hline & Control & 20 & 27.89 & $A^{*}$ & 0. & & 20 & 20.16 & $A^{*}$ & 0.33 \\
\hline $\begin{array}{c}5 \\
\text { lavers }\end{array}$ & $252 \mathrm{~h}$ & 20 & 24.02 & $B$ & 0. & & 20 & 16.86 & $B$ & 0.37 \\
\hline & $504 \mathrm{~h}$ & 20 & 12.47 & C & 0. & & 20 & 7.14 & C & 0.28 \\
\hline
\end{tabular}

The glossiness values of the samples varnished with UV 3- and 5-layer applications decreased as the aging time increased. According to the hardness results, it was determined 
that the PH value increased as the aging time increased in the samples varnished with a UV 5-layer application. It was observed that the samples varnished with a UV 3-layer application first increased after $252 \mathrm{~h}$ of aging and then decreased after $504 \mathrm{~h}$ of aging. During the PH test, the results of the samples vanished with UV 3- and 5-layer applications after $504 \mathrm{~h}$ of aging were found to be higher than the control samples. It was reported by Gurleyen $(2020,2021)$ that the PH values increased, and the adhesion resistance values to the surface decreased after $504 \mathrm{~h}$ of aging in the wood species that had a UV 5-layer varnish system applied. In addition, in the same studies, the PH of samples varnished with a UV 5layer application for were higher than the test samples varnished with a UV 3-layer application. As stated in previous studies, the adhesion strength to the surface of samples varnished with UV 3-and 5-layer applications, before weathering, were 5.720 MPa and 5.840 MPa, respectively, for lemon (Ayata 2019), 3.128 MPa and 3.212 MPa, respectively, for Persian silk (Gurleyen 2020), 2.910 MPa and 2.532 MPa, respectively, for doussie wood (Gurleyen 2021), and 2.004 MPa and 2.260 MPa for this study. According to these results, it was seen that the adhesion strength values of mulberry wood were low when compared to lemon, Persian silk, and doussie wood. In previous studies, the adhesion resistance values decreased during the first period of aging and increased during the last period for the UV 5-layer samples (Ayata 2019; Gurleyen 2020, 2021). Ayata (2019) reported that the reduction in adhesion strength may be due to multiple factors, e.g., wood deterioration, chemical degradation of the coating, and transport of extracts to the wood surface, which affects the bonding line. According to Clerc et al. (2017), the decrease in adhesion resistance can often be caused by the deterioration of wood rather than the chemical degradation of the adhesive, depending on weather conditions. According to the total color difference results, the $\Delta E^{*}$ values of the samples varnished with a UV 3-layer system were greater than the samples varnished with a UV 5-layer system. In addition, it was observed that the $\Delta E^{*}$ values of both varnish types increased as the aging time increased. There was a contrasting situation in the aged UV varnished samples applied by Gurleyen $(2021,2020)$. In this case, it can be said that the different results from the studies originated from different anatomical features of the woods. In addition, it was reported that the different results were obtained due to the different contents of the UV system filling chemicals used in Gurleyen (2021).

\section{CONCLUSIONS}

1. The variance analysis results were significant for all the factors that were considered.

2. In the control samples varnished with a UV 5-layer application, the surface adhesion strength, the pendulum hardness $(\mathrm{PH})$, the parallel $(\|)$ and perpendicular $(\perp)$ glossiness values at $20^{\circ}, 60^{\circ}$, and $85^{\circ}$ angles, and the $a^{*}$ values were greater than the values of the samples varnished with a UV 3-layer application.

3. At the end of $504 \mathrm{~h}$ of aging, it was found that there was an increase in the $\mathrm{PH}$ of $31.45 \%$ in the samples varnished with a UV 5-layer application and $10.48 \%$ in the samples varnished with a UV 3-layer application. These results showed that a 5-layer application was suitable for applications where good stiffness is required, e.g., flooring. 
4. The gloss values of the samples varnished with UV 3- and 5-layer applications perpendicular and parallel to the fibers at $20^{\circ}, 60^{\circ}$, and $85^{\circ}$ angles decreased as the aging time increased.

\section{ACKNOWLEDGMENTS}

The author thanks the KPS factory (Düzce, Turkey), Ümit AYATA, Levent GURLEYEN and Nevzat ÇAKICIER, and Bekir Cihad BAL.

\section{REFERENCES CITED}

ASTM D 2244-3 (2007). "Standard practice for calculation or color tolerances and color differences from instrumentally measured color coordinates," ASTM International, West Conshohocken, PA.

ASTM D 4366-95 (1984). "Standard test methods for hardness of organic coatings by pendulum test," ASTM International, West Conshohocken, PA.

ASTM D 4541 (1995). "Standard test method for pull-off strength of coatings using portable adhesion testers," ASTM International, West Conshohocken, PA.

Ayata, Ü. (2019). "Effects of artificial weathering on the surface properties of ultraviolet varnish applied to lemonwood (Citrus limon (L.) Burm.)," BioResources 14(4), 83138323. DOI: 10.15376/biores.14.4.8313-8323

Ayata, Ü., and Çavuş, V. (2018). "The determination of the surface adhesion resistance and pendulum hardness on the parquets applied UV varnish as single and double layers," Journal of Engineering Sciences and Design 6(4), 541-545. DOI: 10.21923/jesd.388346

Ayata, Ü., Gurleyen, L., Esteves, B., Gurleyen, T., and Cakıcıer, N. (2017). "Effect of heat treatment (ThermoWood) on some surface properties of parquet beech (Fagus orientalis Lipsky.) with different layers of UV system applied," BioResources 12(2), 3876-3889. DOI: 10.15376/biores.12.2.3876-3889

Ayata, Ü., Çakıcıer, N., and Gürleyen, L. (2021). “İç mekânda kullanılan UV sistem parke verniği uygulamasına sahip kayısı odununda yapay yaşlandırma performansının belirlenmesi," Mobilya ve Ahşap Malzeme Araştırmaları Dergisi 4(1), 40-50. DOI: 10.33725/mamad.922311

Blanchard, V., Blanchet, P., and Riedl, B. (2009). "Surface energy modification by radiofrequency inductive and capacitive plasmas at low pressures on sugar maple: An exploratory study," Wood and Fiber Science 41(3), 245-254.

Çavuş, V. (2020a). "Turunç (Citrus aurantium L.) odununun bazı mekanik özelliklerinin belirlenmesi ve bazı odun türleri karşılaştırılması," Mobilya ve Ahşap Malzeme Araştırmaları Dergisi 3(2), 101-109. DOI: 10.33725/mamad.828000

Çavuş, V. (2020b). "Kokulu ardıç odununun bazı fiziksel ve mekanik özellikleri üzerine bir araştırma," Mobilya ve Ahşap Malzeme Araştırmaları Dergisi 3(1), 1-9. DOI: 10.33725/mamad.717060

Clerc, G., Brülisauer, M., Affolter, S., Volkmer, T., Pichelin, F., and Niemz, P. (2017). "Characterization of the ageing process of one-component polyurethane moisture curing wood adhesive," International Journal of Adhesion and Adhesives 72, 130138. DOI: 10.1016/j.ijadhadh.2016.09.008 
Efe, F. T. (2020). “Japon akçaağaç odununun bazı fiziksel ve mekanik özelliklerinin belirlenmesi üzerine bir çalışma," Mobilya ve Ahşap Malzeme Araştırmaları Dergisi 3(2), 110-118. DOI: 10.33725/mamad.837309

Gürleyen, L. (2020). "Effect of artificial weathering on some surface properties of UV system parquet varnish applied to Persian silk (Albizia julibrissin) wood," Turkish Journal of Forestry 21(4), 451-460. DOI: 10.18182/tjf.795597

Gürleyen, L. (2021). "Effects of artificial weathering on the color, gloss, adhesion and pendulum hardness of UV system parquet varnish applied to doussie (Afzelia africana) wood," BioResources 16(1), 1616-1627. DOI: 10.15376/biores.16.1.16161627

Gürleyen, L., Ayata, Ü., Esteves, B., and Cakicıer, N. (2017). "Effects of heat treatment on the adhesion strength, pendulum hardness, surface roughness, color and glossiness of Scots pine laminated parquet with two different types of UV varnish application," Maderas. Ciencia y Tecnologia 19(2), 213-224. DOI: 10.4067/S0718221X2017005000019

Gurleyen, L., Ayata, Ü., Esteves, B., Gürleyen, T., and Cakıcıer, N. (2019). "Effects of thermal modification of oak wood upon selected properties of coating systems," BioResources 14(1), 1838-1849. DOI: 10.15376/biores.14.1.1838-1849

ISO 2813 (1994). "Paints and varnishes - Determination of specular gloss of non-metallic paint films at 20 degrees, 60 degrees and 85 degrees," International Organization for Standardization, Geneva, Switzerland.

ISO 4892-3 (2016). "Plastics - Methods of exposure to laboratory light sources - Part 3: Fluorescent UV lamps," International Organization for Standardization, Geneva, Switzerland.

Schwalm, R. (2006). UV Coatings: Basics, Recent Developments and New Applications Elsevier, Amsterdam, Netherlands.

Söğütlü, C., and Sönmez, A. (2006). "The effect of UV lights on color changes on some local wood processed with differential preservatives," Journal of the Faculty of Engineering and Architecture of Gazi University 21(1), 151-159.

Tekeli, S. T. (1973). IV. Bilim Kongre Tebligleri

TSE - TS 2471 (1976). "Wood - Determination of moisture content for physical and mechanical tests," Turkish Standards Institution, Ankara, Turkey.

TSE - TS 2474 (1976). "Wood - Determination of ultimate strength in static bending," Turkish standard Institute, Ankara, Turkey.

TSE - TS 2477 (1976). "Wood - Determination of impact bending strength," Turkish standard Institute, Ankara, Turkey.

TSE - TS 2478 (1976). "Wood - Determination of modulus of elasticity in static bending," Turkish standard Institute, Ankara, Turkey.

TSE - TS 2479 (1976). "Wood - Determination of static hardness," Turkish Standards Institute, Ankara, Turkey.

TSE - TS EN 13446 (2005). "Wood-based panels - Determination of withdrawal capacity of fasteners," Turkish Standards Institute, Ankara, Turkey.

Yaltırık, F., and Efe, A. (1994). "Dendroloji Ders Kitabı," İstanbul Üniversitesi, Yayın No: 3836, Fakülte Yayın No: 431. İstanbul.

Article submitted: May 24, 2021; Peer review completed: July 11, 2021; Revised version received and accepted: August 11, 2021; Published: August 24, 2021.

DOI: 10.15376/biores.16.4.6791-6798 